Status Report 2016-2019

\title{
Marine and Fluvial Sedimentation Including Erosion and Sediment Flux in Peninsular Indian Phanerozoic Basins
}

SANTANU BANERJEE ${ }^{1, *}$, PARTHASARATHI GHOSH${ }^{2}$, R NAGENDRA $^{3}$, BIPLAB BHATTACHARYA ${ }^{4}$, BHAWANISINGH DESAI ${ }^{5}$ and ASHOK K SRIVASTAVA ${ }^{6}$

${ }^{1}$ Department of Earth Sciences, IIT Bombay, Powai, Mumbai 400 076, India

${ }^{2}$ Geological Studies Unit, Indian Statistical Institute, 203 B.T. Road, Kolkata 700 108, India

${ }^{3}$ Department of Geology, Anna University, Chennai 600 025, India

${ }^{4}$ Department of Earth Sciences, Indian Institute of Technology Roorkee, Uttarakhand, Roorkee 247

667, India

${ }^{5}$ School of Petroleum Technology, Pandit Deendayal Petroleum University, Gandhinagar 382 009, India

${ }^{6}$ Ashok K. Srivastava, Department of Geology, SGB Amravati University, Amravati Maharashtra 444 602, India

(Received on 31 August 2019; Accepted on 28 September 2019)

\begin{abstract}
This review presents a brief appraisal of the present understanding regarding marine and fluvial sedimentation in peninsular India in the background of global tectono-thermal events and relative sea level changes during the Phanerozoic. Sedimentary basins hosting the Phanerozoic deposits of peninsular India can be broadly categorized into two viz. Gondwana related half grabensand Meso-Cenozoic passive margins. Recent investigations document marine incursions in the former category of basins based on careful analysis of trace fossil assemblage and tide- and wave- originated sedimentary structures. The study of continental carbonates in the Upper Gondwana reveals widespread microbially mediated carbonate formation in freshwater systems, while the mud-dominated fluvial deposits in these basins show unique characteristics of the channel to overbank sediment transfer, related to a balance between sediment flux and erosion. The application of sequence stratigraphy provides a high-resolution analysis of passive continental margin sedimentary succession in Kutch, Cauvery and Jaisalmer basins. The origin of authigenic minerals has been integrated with the sequence stratigraphic framework in several Mesozoic and Cenozoic basins. A thorough biostratigraphic investigation reveals different order of sea-level cycles in the sedimentary deposits of Cauvery and Kutch basins and hyperthermal events in the Cenozoic of Kutch. Distinct ichnological assemblages characterize the transgressive and regressive deposits in Kutch and Jaisalmer basins. Quaternary terrestrial sedimentary records provide a high-resolution palaeoclimatic reconstruction.
\end{abstract}

Keywords: Marine Incursion; Continental Carbonate; Sequence Stratigraphy; Fluvial Sedimentation; Passive Margins

\section{Introduction}

Phanerozoic sedimentary basins in peninsular India remained largely protected from the complex tectonic evolution caused by the collision of Indian landmass with the Eurasian block. These basins can be broadly categorized into two viz. half grabens formed within Gondwanaland and Meso-Cenozoic passive margins (Fig. 1). Fault-bounded half-graben type Gondwana basins, located along several palaeo-suture lineaments within the Precambrian cratonic blocks of peninsular India hosts predominantly arenaceous-argillaceous facies succession of continental fluvial origin, and are significant for coal deposits. However, the depositional condition of the Lower Gondwana rocks (late Carboniferous-Permian) has been debated for possible marine influences. Although the Permo-Carboniferous Talchir Formation at the base bears evidence of Late Palaeozoic glaciation, recent studies recognize glaciofluvial, glacio-lacustrine or glacio-marine deposit within

*Authorfor Correspondence: E-mail: santanu@iitb.ac.in 


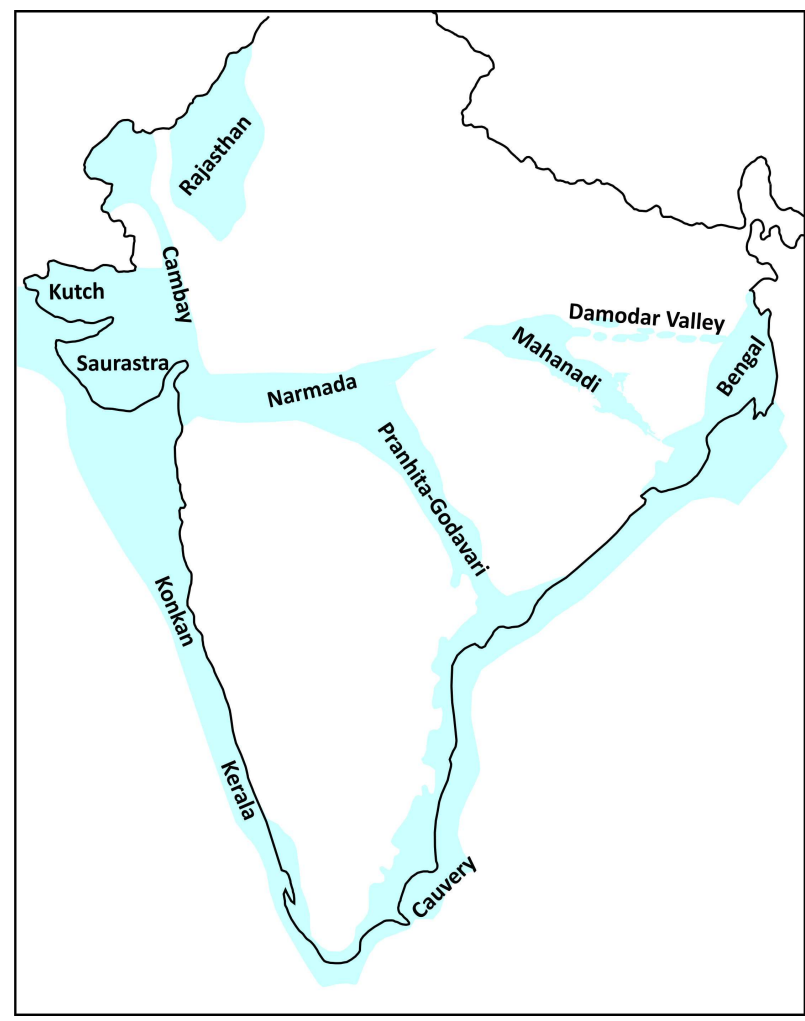

Fig. 1: Distribution of major Phanerozoic sedimentary basins in peninsular India

the Formation (Bhattacharya and Bhattacharya, 2015; Bhattacharya and Banerjee, 2015; Bhattacharya et al., 2018). The Permian coal-bearing Barakar Formation has been reinterpreted in terms of fluvialmarine interactions (Bhattacharya et al., 2016, 2018). Triassic sedimentation in most Gondwana Basins is represented by arkosic to subarkosic sandstone in different basins. Thick quartz arenitic, coarse-grained sandstone of continental origin with occasional tholeiitic basaltic outpouring in some areas characterize the Gondwana sedimentation during the Jurassic time (Sengupta et al., 2016).

During the Middle Jurassic new basins viz Kutch, Cambay and Narmada opened up along the western margin of Peninsular India, related to the breaking of eastern Gondwana from its western counterpart. The sedimentary deposits in these basins record the depositional history at the western margin of Indian craton since its rifting from Madagascar and Seychelles (Biswas, 2016). The Kutch Basin is the earliest to form in the western passive margin of the Indian craton during the break up of Gondwanaland in Late Triassic. The Late Cretaceous Bagh Group in central India represents deposition within the eastwardly transgressing arm of Tethys along the Narmada rift.

Continental rifting followed by seafloor spreading between India, Australia and Antarctica in early Cretaceous opened the east coast of Indian subcontinent (Bastia and Radhakrishna, 2012). Stratigraphic records in these basins can be broadly subdivided into two viz. syn-rift and post-rift. The synrift records can be found up to early Cretaceous in the Cauvery and Krishna-Godavari basins. Whereas Permo-Triassic marks the end of syn-rift sedimentation in Mahanadi and Bengal basins. The objective of this report is to present a brief overview on recent progress in sedimentology and stratigraphy of Phanerozoic basins in peninsular India to highlight fluvial to marine transition and to present changing patterns of sediment flux and erosion, in stratigraphic order.

\section{Glacio-marine and Post-glacial fluvio-marine Deposits in the Lower Gondwana}

Detailed facies analysis supported with trace fossils attributes of the Talchir rocks in Damodar Valley coal basins, Mahanadi Valley coal basins and Satpura basins highlights the basal glacigenic deposition followed by sedimentation in storm-tide influenced icemarginal shallow marine basins (Bhattacharya and Bhattacharya, 2015). The study of the glacialperiglacial processes, assessment of cyclicities and evaluation of sequence stratigraphic architecture across different sub-basins reveal alternating glacial advance-retreat phases with a shift in the palaeoshorelines of the Talchir sea (Bhattacharya and Bhattacharya, 2015). Post-Talchir regression of the strandline caused by glacio-isostatic adjustments led to the deposition of fluvial sediments in fault-controlled terrestrial basins during the early Permian (viz. the Karharbari Formation).

Sandstone-shale-coal cyclothemic facies successions in progradational-retrogradationalstratal packages within the Barakar Formation (early Permian) signify deposition initially in braided to meandering fluvial, later in mixed fluvio-tidal estuary and finally within tide-wave dominated outer estuary. Overall regressive to transgressive shift is attributed to a change in accommodation caused by the base 
level fluctuations in response to post-glacial isostatic adjustments (Bhattacharya et al., 2016, 2018). Phases of sagging triggered by reactivation of basin-marginal faults are demarcated by seismites in different stratigraphic horizons (Bhattacharya et al., 2016).

The Barren Measures Formation (middle Permian), a distinct non-coaliferous lithounit sandwiched between the coal-bearing Barakar and the Raniganj formations, bear evidence of marine encroachments, e.g., abundant tidalites in the sandstone-shale heteroliths and wave generated sedimentary structures, like wave ripples and hummocky cross-stratification. The facies sequence of the Barren Measures Formation suggests a transgressive, tide-wave influenced estuarine depositional system, replacing the previous fluviallacustrine model (Bhattacharya and Banerjee, 2015). This transgression is possibly a consequence of opening up of the Neo-Tethys along the IndoAustralian plate margin (Bhattacharya and Banerjee, 2015). The coarsening-up fluvial sedimentary succession in the overlying Raniganj Formation attests to a predominant regressive phase.

\section{Continental Sedimentation in Upper Gondwana}

The lower part of the Indian Gondwanas (i.e., Lower Gondwanas) has attracted more attention since the early days of exploration because of the presence of economically significant coal deposits and the plentiful occurrence of plant fossils. In recent years, the focus has turned towards the geology of the Upper Gondwana (Dasgupta et al., 2017). Although the Upper Gondwana does not host coal deposits, they provide a wealth of geological information on sedimentary environments existing in various types of continental basins, climatic changes, the evolution of vertebrates and invertebrates, among others.

The Upper Gondwana strata are typically red in colour, which is related to sedimentation in the alluvial environment under arid climatic condition. Further, the absence of marine fossils and wave generated sedimentary structures, the presence of terrestrial fauna and plant remains, and the mineralogical and textural immaturity of sandstones point to deposition in fluvio-lacustrine environment. Triassic and Early Jurassic formations have been extensively studied in recent years to understand the overwhelming dominance of fines in a fluvial deposit and the origin of freshwater carbonates.

\section{Dominance of Fines in the Triassic Fluvial Deposits}

The Middle and the Late Triassic part of the succession are characterized by a few hundreds of meters thick successions of red mudstones interbedded with a few meters thick beds of sandstones. The earlier studies considered sandy beds and mudstones as channel-fill and over bank deposits, respectively. However, it is difficult to explain such a succession in terms of existing fluvial facies models. Traditionally, traction-laden coarse clastics deposit within the channels and fine-grained clastics accumulate in overbank areas. The rate of aggradation is higher in the channel than in the overbank as coarser clastics preferentially deposit within the channels. Besides, the channels receive a more perennial supply of sediments, whereas the overbanks receive sediment input from the channels only during bank-topping flood events. The thickness of the channel-fill deposits is likely to be higher than that of the overbank deposits. The mudstone-dominated character of the Middle and Late Triassic successions contradicts this general trend (e.g., Denwa, Maleri, Tiki formations) of the Upper Gondwanas (Sengupta et al., 2016; Dasgupta et al., 2017; Dasgupta and Ghosh, 2018).

In the Middle Triassic Denwa Formation, Satpura Basin, lensoidal channel-fill bodies occur at several stratigraphic levels encased within very thick pedogenically modified, massive, red mudstones. As these channel-fills contain evidence of deposition of fines, Ghosh et al. (2006) proposed that the lowgradient Denwa fluvial system received a persistent supply of fines-dominated load from the source area. The channels used to relocate through avulsion than through lateral migration. This mode of relocation possibly reduced the probability of autogenic removal of overbank deposits, thereby, augmenting their preservation potential. These workers have identified several splay-avulsion deposits within the mudstone intervals (Ghosh et al., 2006). They suggested that a mechanism for enhanced and more perennial channel to overbank sediment transfer existed during the deposition of the Denwa Formation. Besides, the anabranching character of the fluvial system allowed the interchannel (overbank) areas to receive supply from several adjacent channels, concurrently. 
Similarly, the Late Triassic Maleri Formation in Pranhita-Godavari Basin exhibits a few meter-thick sheet sandstone bodies alternate with few tens of meter-thick intervals of red mudstones. The mudstone intervals consist of laminated, sandy siltstones containing a significant proportion of fine sand-sized pedogenic mud aggregates (Dasgupta et al., 2017). The presence of dune-scale cross-stratification (Fig. $2 a)$ in these fine-grained deposits testifies that the aggregates were transported as bedload by traction current. Dasgupta et al. (2017) proposed that the pedogenic mud aggregate-rich load was transported through a network of shallow, unconfined flow-paths in a discontinuous ephemeral stream system. Rather than size-dependent partitioning of sediments between channel and overbank, the alternation of sheet sandstone bodies and mud aggregate-rich fine-grained sediments reflect changing character of sediment supply, possibly induced by seasonality in precipitation.

The lithological character of the Upper Triassic Tiki Formation of the Rewa Basin and the Lower Triassic Panchet Formation of the Damodar Valley Basin is in many ways similar to that of the Denwa and Maleri formations.

\section{Origin of Freshwater Carbonates Associated with Fluvial Deposits in Upper Gondwana}

A large variety of freshwater carbonates are related to the Upper Gondwana fluvial deposits. Goswami et al. (2018) recently reported various features associated with the subaerial modification of the primary lime mud and algal activity in these limestones. Several studies have reported the occurrences of a rather unusual litho-type in the Middle to Late Triassic strata, viz. calcareous rubbly rock, lime-pellet rock, calcirudite-calcarenite, and grainstone from Maleri, Denwa and Tiki formations (Dasgupta and Ghosh, 2018). The framework of these cross-bedded clastic sedimentary rocks contains coarse sand to small pebble-sized carbonate clasts, admixed with a low amount of other sandy siliciclastic grains. Sarkar (1988) suggested that the microfabric of the grains in the Maleri Formation resemble those of pedogenic concretions. A similar origin has been proposed for those in the Denwa and Tiki formations (Ghosh et al., 2006). In a recent development, Dasgupta and Ghosh (2018) have demonstrated that the grainstones of the Maleri Formation contain clasts of palustrine and spring carbonates. The minute structures formed due to the microbially mediated carbonate precipitation at the sediment-water interface are still preserved in these grains (Fig. 2b). The recognition of signatures of microbial activity in the Late Triassic Maleri Formation and the Early Jurassic Kota Formation opens a new vista for reconstructing the punctuated record of microbial colonization in various freshwater environments during the Mesozoic.

\section{Recent Sedimentological Investigations in Mesozoics of Kutch and Jaisalmer Basins}

Although the Mesozoics in Kutch are well investigated for sedimentological and biostratigraphical implications, significant ichno-sedimentological studies have been carried in recent years. Fourteen major ichnological events are recorded in entire Mesozoic sections of western Kutch, of which six ichno events are documented from Middle Jurassic viz. Diplocraterion-Arenicolites, AstereosomaRhizocorallium, Zoophycos-Chondrites, Zoophycos, Gastrochaeonolites and ZoophycosThalassinoides (Desai, 2016).

The post-rift Upper Jurassic sediments of the Kutch Basin represent a significant regression marked by the development of the "Jhuran Delta" during midKimmeridgian to Tithonian (Desai and Biswas, 2018). Ichnological and sedimentological parameters define fourteen lithofacies and seven lithofacies associations corresponding to various sub-environments in riverdominated and wave-influenced Jhuran Delta. The prodelta environment exhibits moderate ichnodiversity suggesting alternating brackish and fully saline water conditions (Desai and Biswas, 2018). Delta front and distributary mouth bar show moderate ichnodiversity of mixed river and marine environment. The Early Cretaceous shoreface deposited sands of the Katesar Member reveal the rich diversity of trace fossils forming Gyrophyllite-Diplocraterion ichnoassemblage (Desai, 2016). Palaeocommunity dynamics analysis within the Guneri Member reflects oscillatory flow conditions related to tide (Desai and Saklani, 2015). Bansal et al. (2017) provided the sequence stratigraphic framework of the Ukra Hill Member. Based on abundance and $\mathrm{K}_{2} \mathrm{O}$ content of glauconite, these authors have distinguished the transgressive systems tract (TST) from highstand systems tract (HST) deposits, separated by a 

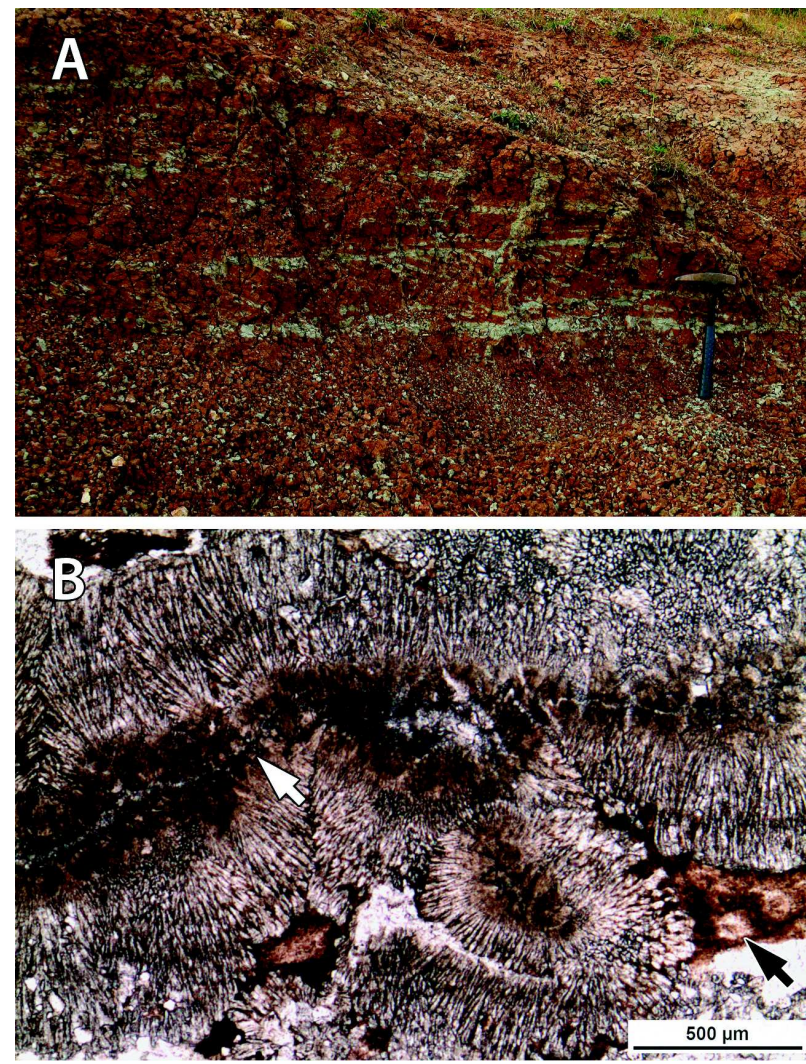

Fig. 2: A) Dune-scale planar cross-beds (parallel to hammer head) in the red clayey siltstone of the Late Triassic Maleri Formation, Pranhita-Godavari Gondwana Basin. B) Photomicrograph of Maleri carbonate showing a curled flake with dark micritic core (white arrow) coated by clear calcite crystal dendrites. The interstitial space is filled with iron-stained clays, containing organic matter (black arrow)

glauconite-rich condensed zone. A thorough study of constituent facies in the lower part of the Bhuj Formation reveals an explicit record of relative sea level rise between two fluvial stratigraphic intervals and the development of estuarine conditions (Mandal et al., 2016). A few studies focus on the source of Mesozoic sediments in the Kutch Basin based on integration of petrography, major and trace element concentration and heavy mineral chemistry (Chaudhuri et al., 2018, 2019). The Jhuran Formation has been investigated for the possible anoxic event during the Jurassic (Arora et al., 2015, 2017).

Pandey and Pooniya (2015) presented the sequence stratigraphic framework of the Baisakhi Formation (Oxfordian to Tithonian) in Jaisalmer Basin. These authors presented a general coarsening-upward trend, accompanied by a change from the lower shoreface zone to the fluvial environment within the Kimmeridgian-Tithonian part of the Baisakhi Formation. Dolson et al. (2015) presented a detailed analysis of the sedimentary sequence in the Barmer Basin. These authors considered a rift sequence of Mesozoic fluvial rocks in this basin which is followed upward by an infilling of rift accommodation space by the deposition of fluvial, lacustrine and shallow marine sediments during Palaeocene-Eocene.

\section{Transgressive and Regressive Cycles in the Cauvery Basin}

The Cauvery Basin is a Mesozoic pericratonicrift basin filled with syn-rift fluvial and lacustrine sediments (Nagendra et al., 2018), overlain by marine sediments. The excellent preservation of planktic foraminifera assigns a Late Aptian age for the transgressive upper part of the Terani Formation. This marine transgression event of the Terani Formation is a corollary to the terminal phase of syn-rift tectonics in the Cauvery Basin. Subtle unconformity across Terani and Dalmiapuram formations (Aptian/Albian) and major unconformities across the Karai and Garudamangalam formations (Late Turonian) and Sillakkudi and Kallankurichchi formations (Late Campanian) have equivalents in the adjoining KrishnaGodavari Basin (Raju and Reddy, 2016). The Karai Formation, exposed at the basin margin, contains diverse assemblages of ammonites, foraminifera and radiolarian and consists predominantly of glauconitic shale with abundant calcareous benthic foraminifera suggesting deposition in $>150 \mathrm{~m}$ water depth (Fig. 3; Banerjee et al., 2016a; Nagendra et al. 2018). The age of the Karai Shale, marking a major transgressive cycle ranges from Early Albian to Middle Turonian (Gowtham et al., 2019). The Albian age, indicated by index fossil taxa, as well as new Ar/Ar dating of glauconite significantly improves the calibration of OAE $1 \mathrm{~d}$ in the Cauvery Basin (Nagendra and Reddy, 2017; Bansal et al., 2019a).The transition from the shallow shelf-originated Dalmiapuram Formation to the deeper shelf-originated Karai Shale Formation records a transgressive trend (Sarkar et al., 2014).

Ichnofossil assemblage in the Kulakkalnattam Sandstone Member of the Garudamangalam Formation coincides with a rapid relative sea-level fall from deep outer neritic to inner neritic depth during 
the Late Turonian. The ichnofossil assemblage consists mainly Skolithos and Cruziana, suggesting a typical shoreface, environment (Nagendra et al., 2011). The marine carbonates in Kallankurichchi Formation are enriched in mollusks, including Gryphaea, Alectronia, Pecten and bryozoans that represent maximum flooding surfaces (Nagendra et al., 2011). This unit also contains well preserved larger benthic foraminifera, particularly the LepidorbitoidesSiderolites assemblage (Malarkodi et al., 2017) and planktic foraminifera Globotruncanaaegyptiaca, $G$. linneiana and $G$. arca, corresponding to the zone CF6 of the late Early Maastrichtian (Keller et al., 2016). Recent magnetostratigraphic investigations reveal thirteen magnetozones comprising of 6 normal and 7 reversal events within the Cauvery Basin (Nagendra and Reddy, 2017). These polarity events corroborate with chron C34n to chron C30n of the Geologic Time Scale of Gradstein et al. (2012) and indicate a low southern latitude during the Late Cretaceous period for the Cauvery Basin.

\section{Marine and Continental Deposits in Bagh Group and Lameta Formation}

Cretaceous marine transgression has been revisited in Nimar Sandstone and Nodular Limestone with new sedimentological, palaeontological, ichnological and micropalaeontological data (Bhattacharya and Jha, 2014; Jhaet al., 2017). Jha et al. (2016) reported seismites, in the middle part of the Nimar Sandstone and interpreted a new phase of reactivation of the Son-Narmada South Fault during the Cenomanian period. These authors suggested that the lower part of litho-unit shows predominantly fluvial deposits, whereas the middle and upper parts exhibit tidedominated estuarine to tide-wave influenced shoreface condition. Stacked fining-up transgressive cycles signify a rise in base level during the Cenomanian-Turonian accompanied by basinal subsidence caused by reactivation of basin marginal faults in the Narmada rift valley basin (Jha et al., 2017). The subsidence caused the encroachment of open sea, hence further landward inundating the entire basin.

Racey et al. (2016) proposed a revised chronostratigraphic framework for the Bagh Group of rocks. Patel et al. (2018) reported trace fossils viz. Conichnusconicus, Conostichusbroadheadi and C. stoutifrom intercalated micritic limestone shale sequence of the Bagh Group of rocks exposed in Man river basin. They have interpreted these ichnospecies as resting/dwelling structures characterizing a shallow marine environment of deposition. Ruidas et al. (2018) revisited the stratigraphic set-up and proposed a new division of the Nodular Limestone and also explained the nature and origin of modularity. Kumar et al. (2018) proposed a Turonian age for the Nodular Limestone Formation of Bagh area based on ammonoid and Inoceramus index taxa. Recently, Bansal et al. (2019b) reported a glauconite bed within the Late Bryozoan Limestone Formation of the Bagh Group in central India. These authors recorded the existence of a 'glauconitic sea' along the margins of the Palaeo-Tethys Ocean during the Late Cretaceous on the basis of existing records and detailed geochemical analysis.

The Lameta Formation of the Maastrichtian age, traditionally considered to be fluvial, reveals the evidence of short-lived marine incursion based on careful analysis of ichnofossils, lithological architecture, calcareous algae (Srivastava et al., 2018) and authigenic glauconite (Bansal et al., 2018). Mankar and Srivastava (2015) proposed a new basin of deposition for the Lameta sediments in central India, viz., Salbardi-Belkhar inland basin and identified three different lithofacies reveling fluvial-lacustrine set-up for the same. Dinosaur remains and egg nests have been reported in recent studies (Srivastava and Mankar, 2015; Aglawe and Lakra, 2018; Fernández and Khosla, 2015; Khosla et al., 2015). Sonkusare et al. (2016) reported plant remains and diverse spores and pollens within Lameta sediments.

\section{Facies and Sequence Stratigraphic Analysis the Cenozoic Successions in Kutch and Jaisalmer}

The sequence stratigraphic architecture of the Palaeogene succession of Kutch has been addressed in recent studies based on the detailed sedimentary facies and biostratigraphic analysis (Fig. 4; Chattoraj et al., 2016; Catuneanu and Dave, 2017; Banerjee et al., 2018; Srivastava and Singh, 2019). The Naredi Formation, overlying the unfossiliferous Matanomadh Formation, represents the products of the earliest marine transgression in the Palaeogene of Kutch (Chattoraj et al., 2009; Sarkar et al., 2012; Saraswati et al., 2012). The presence of age-diagnostic benthic 


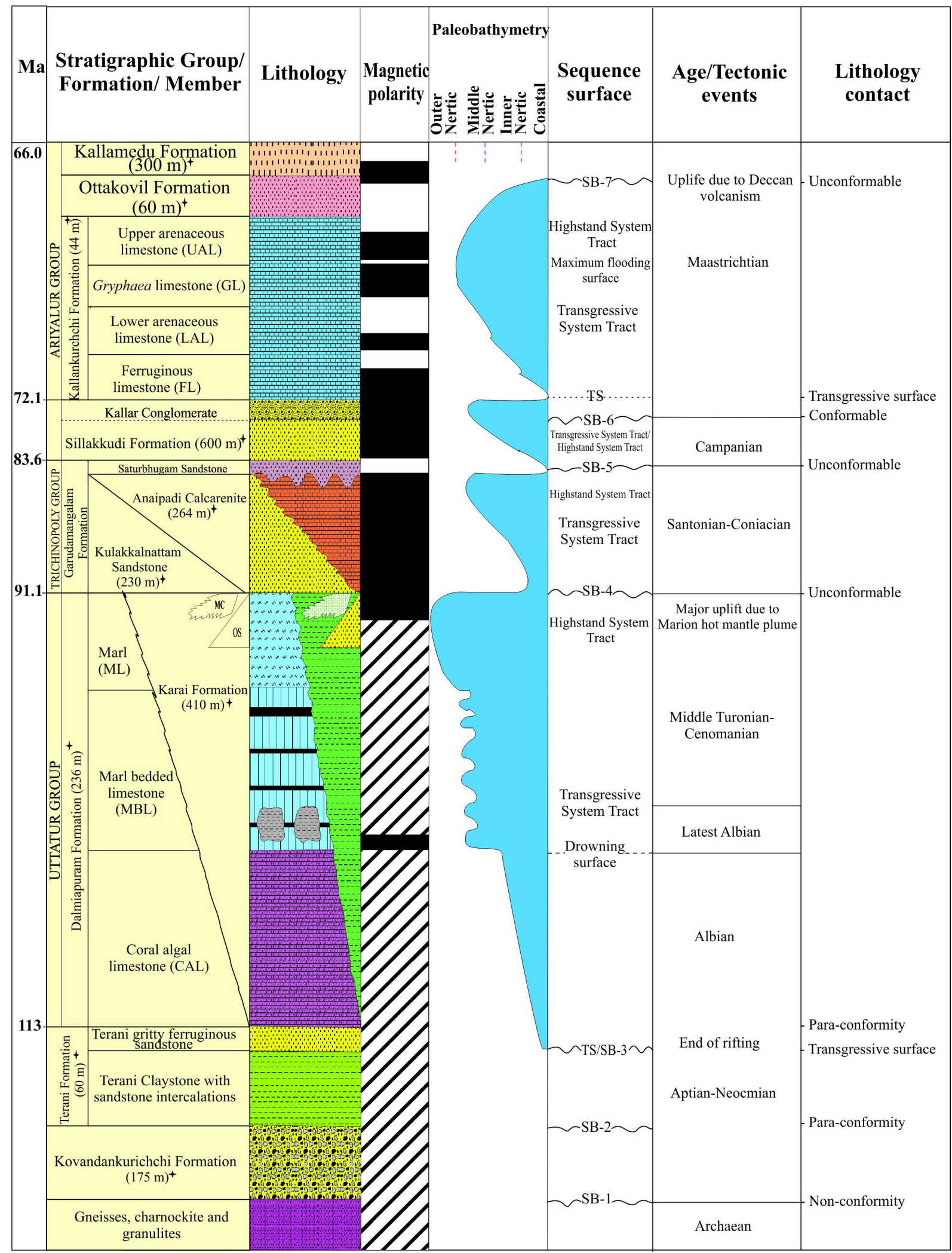

Normal $\square$ Reversal $\quad \mathbb{Z} /$ Not measured MC: Maruvattur Claystone OS: Odhiyam Sandstone + Thickness after Sundram et al., 2001 SB-Sequence Boundary TS- Transgressive surface

Fig. 3: Litholog showing palaeobathymetric varations, key sequence stratigraphic surfaces, tectonic and magnetic polarity events 
foraminifera assigns an Early Eocene age for the lower part of the Naredi Formation (Saraswati et al.,2014, 2018; Khanolkar et al., 2017). The lower part of the glauconitic Naredi Formation records an overall deepening upward trend until the deposition of an Assilina-bearing limestone, representing a transgressive systems tract (TST). The upper part of the Naredi Formation shows an overall shallowing upward trend and comprises the highstand systems tract (HST). An extended break in sedimentation follows this HST (Chattoraj et al., 2016; Catuneanu and Dave, 2017; Saraswati et al., 2016a,b,2018). The unconformity at the contact between the Naredi and Harudi formations is marked by regionally extensive laterite (Banerjee et al., 2012a, 2018). A combined sedimentological and micropalaeontological analysis reveals an overall deepening upward trend within the Harudi Formation (Banerjee et al., 2012a; Chattoraj et al., 2016). The overall deepening upward,glauconitic Harudi Formation represents a transgressive systems tract which is followed upward by the shallow marine Fulra Limestone. The latter is dominated by nummulite accumulations and exhibits several smaller order sealevel oscillations (Chattoraj et al., 2012; Banerjee et al., 2018). A prominent palaeokarst surface at the top of the Fulra Limestone represents a distinct break in sedimentation during the Late Eocene time (Banerjee et al., 2018). A glauconitic shale marks the transgressive lower part of the Oligocene Maniyara Fort Formation (Banerjee et al., 2012b, 2018). Banerjee et al. (2016b) indicated that the origin of shallow marine glauconites in the Palaeogene of Kutch might be different from those forming in the modern deep marine environment.

A carbonate-siliciclastic deposit represents the Early Miocene succession in Kutch, consisting of Khari Nadi and Chhasra Formation. A combined sedimentological, trace fossil assemblage and micropalaeontological analysis reveals the sequence stratigraphic background and identifies key stratal surfaces (Kumar et al. 2016). The transgressive systems tract exhibits a gradual change in foraminiferal assemblage indicating deepening-upward succession in the overall middle shelf environment, accompanied by a change of trace fossil assemblage from Psilonichnus to Skolithos and finally to Thalassinoides assemblage, from the bottom to the top (Kumar et al., 2016). Shekhar et al. (2018) presented the sequence stratigraphic frame for the Middle to Upper Miocene Sandhan Formation. These authors considered the Sandhan Formation as a product of wave-dominated TST and HST followed by the forced regressive deposit of FSST.

Patra and Singh (2015) presented a detailed facies analysis of the Palaeocene-Eocene succession of the Jaisalmer Basin and inferred that the sandstones deposited in shoreface to foreshore zone and the carbonate-shale alternations formed in lagoonal and tidal environments within a mixed siliciclasticcarbonate ramp/platform.

\section{Palaeogene Hyperthermal Events in Kutch}

In the past decades, there have been two major developments of consequence to the Palaeogene stratigraphy. Firstly, the biostratigraphy of the Tethyan shallow marine successions has been refined by Shallow Benthic Zonation to facilitate regional correlations. Secondly, global hyperthermal events of the Eocene, marked by carbon isotope excursions (CIE), are also recognized in the marginal marine to shallow marine sequences of India (Khanolkar and Saraswati, 2015; Khanolkar et al., 2017). These hyperthermal events are marked by enhanced weathering and erosion and an increase in hydrological intensity. The identification of these events necessitated updating the biostratigraphy of the best developed Palaeogene sequence of India in Kutch. The larger benthic foraminifera comprising Nummulites, Lepidocyclina and orthophragminids were re-studied biometrically to compare them with their current taxonomy in western Tethyan sequences (Saraswati et al., 2018). These biostratigraphic studies integrated with Sr-isotope stratigraphy have led to propose shallow benthic zonation and an updated stratigraphy of the Palaeogene (Saraswati et al., 2018). While the CIEs are marked in the Cambay Basin, the effect of warming on shallow marine foraminifera has been attempted in Cambay and Kutch basins (Sharma and Saraswati, 2015; Khanolkar and Saraswati, 2015, 2016; Khanolkar et al., 2017; Khanolkar and Sharma, 2019). However, the role of hyperthermal events on enhanced chemical weathering of terrestrial silicates is yet to be documented from the Palaeogene deposits in India. 


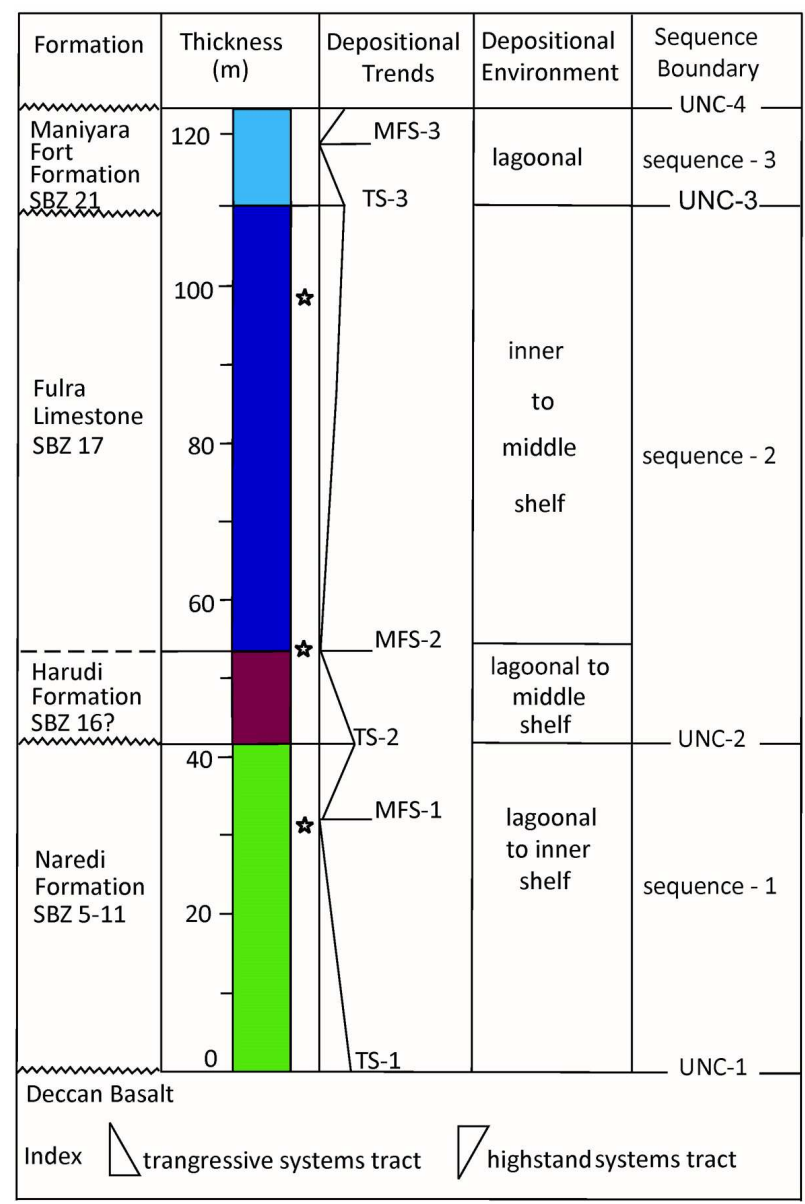

Fig. 4: A composite graphic log of the Palaeogene succession of Kutch showing unconformities, transgressive surfaces, maximum flooding surfaces and systems tracts. Occurrences of glauconite marked by asterisks. (modified after Chattoraj et al., 2016)

\section{Quaternary Sedimentation and Palaeoclimaticre Construction}

In last few years, considerable progress has been made towards Quaternary terrestrial sedimentation and palaeoclimatic reconstruction (Raj et al., 2015; Sridhar et al., 2016; Sridhar and Chamyal, 2018; Khonde et al., 2017a, b; Prizomwala et al., 2018). Contribution have also been made on calcrete profilling (Srivastava and Basand, 2019), palaeosol geochemistry (Srivastava et al., 2019) and nature, occurrence, lithological and depositional set-up of Youngest Toba Tuff(YRR) ash (Srivastava and Singh, $2019 b$ ) that are preserved in Quaternary alluvial sediments of Purna basin, Central India. Based on the study of sediments in Pariyaj Lake in Gujarat Plains Raj et al. (2015) indicated a wet climate and high lake stand during $\sim 11,000,7630$ and between 4680 and $3500 \mathrm{cal} \mathrm{yr} \mathrm{BP.} \mathrm{Bhushan} \mathrm{et} \mathrm{al.} \mathrm{(2018)} \mathrm{indicated} \mathrm{a}$ persistent millennial to centennial-scale monsoon variability during the Holocene within relict lake sediments occurring at the boundary between lesser and higher central Himalayas. Based on high-resolution geochemical data supported by radiocarbon dating, these authors inferred six phases of enhanced Indian Summer Monsoon (ISM) with varying scales between 10,000-9600, 9500-9200, 8600-5800, 5000-4200, 35002400 and 1800-1000 cal yr BP. Misra et al. (2018) compiled lake records from India and found that only about 14 lake records provide a reasonably timeresolved natural climate variability throughout the Holocene, and only 9 other lake records provide palaeoclimate information for a duration of more than $\sim 8$ kyr. Khonde et al. (2017b) indicated that the lost Saraswati River mentioned in the ancient Indian tradition is postulated to have flown independently of the Indus River into the Arabian Sea, perhaps along courses of now-defunct rivers such as Ghaggar, Hakra and Nara. Sridhar et al. (2016) documented the record of the Little Ice Age based on the temporal variations in the major and trace elements and the $\mathrm{Sr}$ and $\mathrm{Nd}$ isotopic composition of the silicate component of palaeoflood deposits. Their study demonstrates that the geochemical signatures of the flood sediment are largely controlled by the weathering intensity in the catchments, the river discharge and mineral sorting.

Saha et al. (2016) presented the morphology and evolution of tidal sand ridges and bars in the macrotidal Gulf of Khambhat. They reported several km long, narrow and several meters high ridges within the outer gulf. While the sand bars associated with macrotidal estuaries along the flanks of Gulf of Khambhat typically range in length from a few $100 \mathrm{~m}$ to a few $\mathrm{km}$ long. Saha et al. (2018) reported the uniqueness in the tide-dominated sediment depositional system based on their study of Tapti, Narmada, Dhadhar and Mahi estuaries. These authors documented a mixing of sediments as fluvial currents interact with and tidal flows.

\section{Concluding Remarks}

The Phanerozoic sedimentary record in the Peninsular India holds promises of hosting significant evidence of tectono-eustatic fluctuations, plate tectonic reconstruction and the evolution of Earth's atmosphere 
and hydrosphere. An integration of sedimentological and palaeobiological data has provided a highresolution interpretation of stratigraphic records. Although significant progress has been made in recent years, a detailed study on source-to-sink systems is necessary to indicate sediment generation and associated routing systems including erosion, sediment

\section{References}

Aglawe V A and Lakra P(2018) Upper Cretaceous (Maastrichtian) dinosaur eggs Megaloolithuscyl indricus from SalbardiGhorpend area, Betul district, Madhya Pradesh J Pal Soc India 63 191-196

Arora A, Banerjee S and Dutta S (2015) Black shale in Late Jurassic Jhuran Formation of Kutch: Possible indicator of Oceanic Anoxic Event $J$ GeolSoc India 85 265-278

Arora A, Dutta S, Gogoi B and Banerjee S (2017) The effects of igneous dike intrusion on organic geochemistry of black shale and its implications: Late Jurassic Jhuran Formation, India Int J Coal Geol 178 84-99

Banerjee S, Chattoraj S L, Saraswati P K, Dasgupta S and Sarkar U (2012a) Mineralogy and geochemistry of lagoonal glauconites and their implications on origin and maturation: Oligocene Maniyara Fort Formation, western Kutch, India Geol J 47 357-371

Banerjee S, Chattoraj S L, Saraswati P K, Dasgupta S and Sarkar $\mathrm{U}(2012 \mathrm{~b})$ Substrate control on formation and maturation of glauconites in the Middle Eocene Harudi Formation, western Kutch, India Mar Petrol Geol 30 144-160

Banerjee S, Bansal U, Pande K and Meena SS (2016a) Compositional variability of glauconites within the Upper Cretaceous Karai Shale Formation, Cauvery Basin, India: implications for evaluation of stratigraphic condensation Sediment Geol 331 12-29

Banerjee S, Bansal U and Thorat A (2016b) A review on palaeogeographic implications and temporal variation in glaucony composition J Palaeogeogr 5 43-71

Banerjee S, Khanolkar S and Saraswati P K (2018) Facies and depositional settings of the Middle Eocene-Oligocene carbonates in Kutch Geodinamica Acta 30 119-136

Bansal U, Banerjee S, Pande K, Arora A and Meena S S (2017) The distinctive compositional evolution of glauconite in the Cretaceous Ukra Hill Member (Kutch Basin, India) and its implications Mar Petrol Geol 82 97-117

Bansal U, Banerjee S, Ruidas D K and Pande K (2018) Origin and geochemical characterization of the glauconites in the Upper flux, deposition and storage.

\section{Acknowledgement}

Authors are thankful to respective institutes for infrastructure facilities. They also thank various science funding agencies of Government of India for the financial support.

Cretaceous Lameta Formation, Narmada Basin, Central India J Palaeogeogr 7 99-116

Bansal U, Pande K, Banerjee S, Nagendra R and Jagadeesan K C (2019a) The timing of oceanic anoxic events in the Cretaceous succession of Cauvery Basin: Constraints from $40 \mathrm{Ar} / 39 \mathrm{Ar}$ ages of glauconite in the Karai Shale Formation Geo J 54 308-315

Bansal U, Banerjee S, Pande K and Das DK (2019b) Unusual seawater composition of the Late Cretaceous Tethys imprinted in glauconite of Narmada basin, central India Geol Mag https://doi.org/10.1017/ S0016756819000621

Bastia R and Radhakrishna M (2012) Basin Evolution and Petroleum Prospectivity of the Continental Margins of India. Developments in Petroleum Science 59 Elsevier Oxford

Bhattacharya B and Jha S (2014) Late Cretaceous diurnal tidal system: A study from Nimar Sandstone, Bagh Group, Narmada Valley, Central India Current Science 107 10321037

Bhattacharya B and Banerjee P P (2015) Record of Permian Tethyan transgression in eastern India: A reappraisal of the Barren Measures Formation, West Bokaro Coalfield Mar Petrol Geol 67 170-179

Bhattacharya B, Bhattacharjee J, Banerjee S, Bandyopadhyay S and Das R (2016) Seismites in Permian Barakar Formation, Raniganj Basin, India: implications on Lower Gondwana basin evolution Arab J Geoscience 9300

Bhattacharya B, Bhattacharjee J, Bandyopadhyay S, Banerjee S and Adhikari K (2018) Early Permian transgressiveregressive cycles: sequence stratigraphic reappraisal of the coal-bearing Barakar Formation, Raniganj Basin, India $J$ Earth Sys Sci 12729 https://doi.org/10.1007/s12040-0180922-7

Bhattacharya H N and Bhattacharya B (2015) Lithofacies architecture and paleogeography of Late Paleozoic glaciomarine Talchir Formation, Raniganj Basin, India $J$ Palaeogeogr 4 269-283

Bhushan R, Sati, SP, Rana, N, Shukla AD, Mazumdar AS and 
Juyal N (2018) High-resolution millennial and centennial scale Holocene monsoon variability in the Higher Central Himalayas Palaeo Palaeo Palaeo 489 95-104

Biswas S K (2016) Tectonic framework, structure and tectonic evolution of Kutch Basin, western India Spec Publ Geol Soc India 88 129-150

Catuneanu O and Dave A (2017) Cenozoic sequence stratigraphy of the Kachchh Basin, India Mar Petrol Geol 86 11061132

Chattoraj S, Banerjee S and Saraswati P K (2009) Glauconites from the late Palaeocene Early Eocene Naredi Formation, Western Kutch and their genetic implications $J$ GeolSoc India 73 567-574

Chattoraj S L, Sarkar U, Banerjee S and Saraswati P K (2012) Facies and Paleogeography of the Middle Eocene Fulra Limestone Kutch J Indian Asso Sediment 31 1-10

Chattoraj S L, Banerjee S, Saraswati P K and Bansal U (2016) Origin, depositional setting and stratigraphic implications of Palaeogene glauconite of Kutch Spl Publ Geo Soc India $675-88$

Chaudhuri A, Banerjee S and Le Pera E (2018) Petrography of Middle Jurassic to Early Cretaceous sandstones of the Kutch Rift Basin: Implications on provenance and basin evolution J Palaeogeogr 7 239-252

Chaudhuri A, Banerjee S and Chauhan G (2019) Compositional evolution of sediments recording the increasing tectonic stability of a pericratonic rift: Mesozoic Kutch Basin, western India Mar Petrol Geol https://doi.org/10.1016/ j.marpetgeo.2019.08.026

Dasgupta S and Ghosh P (2018) Freshwater carbonates within a Late Triassic siliciclastic fluvial system in a Gondwana rift basin: The Maleri Formation, India Sed Geol 373254 271

Dasgupta S, Ghosh P and Gierlowski-Kordesch E (2017) A Discontinuous Ephemeral Stream Transporting Mud Aggregates In. A Continental Rift Basin: The Late Triassic Maleri Formation, India J Sediment Res 87 838-865

Desai B G (2016) Ichnological Events Associated with Evolution of Kachchh Rift Basin, Western India. In M Thakkar (Ed.) Recent Studies on the Geology of Kachchh Spl Publ Geo Soc India 6 114-128

Desai G and Saklani R D (2015) Palaeocommunity Dynamics and Behavioral Analysis of Conichnus: Bhuj Formation (Lower Cretaceous), Kachchh-India Ichnos 22 43-55

Desai B G and Biswas S K (2018) Postrift deltaic sedimentation in western Kachchh Basin: Insights from ichnology and sedimentology Palaeo Palaeo Palaeo 504 104-124
Dolson J, Burley, S D, Sunder, V R, Kothari, V, Naidu, B, Whiteley, N P, Farrimond, P, Taylor A, Direen N and Ananthakrishnan B (2015) The Discovery of the Barmer Basin, Rajasthan, India, and its petroleum geology AAPG Bull 99 433-465

Fernández M S and Khosla A (2015) Parataxonomic review of the Upper Cretaceous dinosaur eggshells belonging to the family Megaloolithidae from India and Argentina Hist Biol 27 158-180

Ghosh P and Sarkar S (2011) Pedogenic and sedimentologic criteria for recognition of overbank sub-environments in a Triassic anabranching river deposit: In: From River to Rock Record: The Preservation of Fluvial Sediments and Their Subsequent Interpretation (Eds: Davidson S K, Leleu S and North C P) SEPM Special Publication 97 125-142

Ghosh P, Sarkar S and Maulik P (2006) Sedimentology of a muddy alluvial deposit: Triassic Denwa Formation, India Sed Geol 191 3-36

Goswami S, Gierlowski-Kordesch E and Ghosh P (2018) Sedimentology of the Early Jurassic limestone beds of the Kota Formation: record of carbonate wetlands in a continental rift basin of India J Paleolimnol 59 21-38

Gowtham J P, Pandey B, Jaitly A K, Pathak D B, Kumar S and Tiwari D N (2019) Early Albian Ammonites from the Karai Formation, Cauvery Basin, South India Earth Sci India 12 53-70

Gradstein F M, Ogg J G, Schmitz M D and Ogg G M (2012) The Geological Time Scale. Amsterdam, Elsevier

Jha S, Bhattacharya B and Nandwani S (2017) Significance of seismites in the Late Cretaceous transgressive Nimar Sandstone succession, Son-Narmada rift valley, Central India Geol J 52 768-783

Keller G, Jaiprakash B C and Reddy A N (2016) Maastrichtian to Eocene subsurface stratigraphy of Cauvery Basin and correlation with Madagascar J Geo Soc India 87 3-34

Khanolkar S and Saraswati P K (2015) Ecological response of shallow-marine foraminifera to early Eocene warming in equatorial India J Foram Res 45 293-304

Khanolkar S and Saraswati P K (2016) Some observations on an atypical planktic foraminifer from the Middle Eocene of Kutch, India J Micropalaentol 35 54-61

Khanolkar S and Sharma J (2019) Record of Early to Middle Eocene paleoenvironmental changes from lignite mines, western India $J$ Micropalaeontol 38 1-24

Khanolkar S, Saraswati P K and Rogers K (2017) Ecology of foraminifera during the middle Eocene climatic optimum in Kutch, India Geodinamica Acta 29 181-193

Khonde N N, Maurya D M and Chamyal L S (2017a) Late 
Pleistocene-Holocene clay mineral record from the Great Rann of Kachchh basin, Western India: Implications for palaeoenvironments and sediment sources QuatInt 443 86-98

Khonde K, Singh S K, Maurya D M, Rai V K, Chamyal L S and Giosan L (2017b) Tracing the Vedic Saraswati River in the Great Rann of Kachchh Sci Rep 75476

Khosla A, Chin K, Alimohammadin H and Dutta D (2015) Ostracods, plant tissues, and other inclusions in coprolites from the Late Cretaceous Lameta Formation at Pisdura, India: Taphonomical and palaeoecological implications Palaeo Palaeo Palaeo 418 90-100

Kumar P, Saraswati P K, Banerjee S and Ghosh A(2016) Sequence stratigraphic analysis of a shallow marine, mixed carbonatesiliciclastic system, early Miocene, Kutch Spl Publ Geo Soc India 6 55-74

Kumar S, Pathak D B, Pandey B, Jaitly A K and Gautam J P (2018) The age of the Nodular Limestone Formation (Late Cretaceous), Narmada Basin, central India J Earth Sys Sci 127 doi: Org/10.1007/S12040-018-1017-1

Malarkodi N, Özcan E, Venkataraman D, Suresha Gowda S C, Nagaraja P K T and Ali O (2017) Lepidorbitoides (foraminifera) from the lower Maastrichtian Kallankurichchi Formation, Cauvery Basin, India: Morphometry and paleobiogeography Cret Res 77 143157

Mandal A, Koner A, Sarkar S, Tawfik H A, Chakraborty N, Bhakta S and Bose P K (2016) Physico-chemical tuning of palaeogeographic shifts: Bhuj Formation, Kutch, India Mar Petrol Geol 78 474-492

Mankar R S and Srivastava A K (2015) Salbardi-Belkher inland basin: a new site of Lameta sedimentation at the border of districts Amravati, Maharashtra and Betul, Madhya Pradesh, Central India Current Science 109 1337-1344

Misra P, Tandon S K and Sinha R (2018) Holocene climate records from lake sediments in India: Assessment of coherence across climate zones. Earth-Science Reviews https:// doi.org/10.1016/j.earscirev.2018.12.017

Nagendra R and Nallapa Reddy A(2017) Major geological events of the Cauvery Basin, India and their correlation with global signatures-A Review J Palaeogeogr 6 69-83

Nagendra R, Kamalakkannan B V, Sen G, Gilbert H, Bakkiaraj D, Nallapa Reddy A and Jaiprakash B C (2011) Sequence surfaces and paleobathymetric trends in Albian to Maastrichtian sediments of Ariyalur area, Cauvery Basin, India Mar Petrol Geol 28 895-905

Nagendra R, Sathiyamoorthy P, Reddy A N, Gilbert H and Jaiprakash B C (2013) Stratigraphic status, age and paleobathymetry of the Grey Shale Member of the Dalmiapuram Formation, Cauvery Basin, India Arabian J Geos 7 4133-4144

Nagendra R, Reddy A N, Jaiprakash B C, Gilbert Harry, Zakharov D Y and Venkateshwarlu M (2018) Integrated Cretaceous stratigraphy of the Cauvery basin, south India Stratigraphy $15245-259$

Pandey D K and Pooniya D (2015) Sequence stratigraphy of the Oxfordian to Tithonian sediments (Baisakhi Formation) in the Jaisalmer Basin Volumina Jur 13 65-76

Patel S J, Shitole AD and Joseph J K (2018) Plug shaped burrows Conichnus-Conostichus from the Late Cretaceous of Bagh Group, Gujarat, Western India J Geol Soc India 91 41-46

Patra A and Singh B P (2015) Facies characteristics and depositional environments of the Paleocene-Eocene strata of the Jaisalmer basin, western India Carb Evap 30 331346

Prizomwala S P, Yadav G, Bhatt N and Sharma K (2018). Late Pleistocene relative sea-level changes from Saurashtra, west coast of India Curr Sci 115 2297-2301

Racey A, Fisher J, Bailey H and Roy S K (2016) The value of fieldwork in making connections between onshore outcrops and offshore models: an example from India: In: The value of outcrop studies in reducing subsurface uncertainty and risk in hydrocarbon exploration and production (Eds: Bowman M, Smyth H R, Good T R, Passey S R, Hirst J P P and Jordan C J) Spl Publ Geol Soc London 436 https:/ /doi.org/10.1144/SP436.9

Raj R, Chamyal L S, Prasad V, Sharma A, Tripathi J K and Verma P (2015) Holocene climatic fluctuations in the Gujarat Alluvial Plains based on a multiproxy study of the Pariyaj Lake archive, western India Palaeo Palaeo Palaeo 421 6074

Raju D S N and Reddy A N (2016) Why there is a substantial dichroneity in biostratigraphic dating of Cretaceous sediments in the Krishna-Godavari Basin and Cauvery Basin -a review ONGC Bull 51 119-134

Ruidas D K, Paul S and Gangopadhyay T K (2018) A reappraisal of stratigraphy of Bagh Group of rocks in Dhar District, Madhya Pradesh with an outline of origin of nodularity of Nodular Limestone Formation J Geol Soc India 92 19-26

Saha S, Burley S, Banerjee S, Ghosh A and Saraswati P K (2016) The morphology and evolution of tidal bar sand bodies in the macrotidal Gulf of Khambhat, western India Mar Petrol Geol 74 714-730

Saha S, Burley S and Banerjee S (2018) Mixing processes in modern estuarine sediments from the Gulf of Khambhat, western India Mar Petrol Geol 91 599-621 
Saraswati P K, Sarkar U and Banerjee S (2012) Nummulites solitarius - Nummulitesburdi galensis lineage in Kutch with remarks on the age of Naredi Formation J Geo Soc India 79 476-482

Saraswati P K, Khanolkar S, Raju D S N, Dutta S and Banerjee S (2014) Foraminiferal biostratigraphy of lignite mines of Kutch, India: Age of lignite and fossil vertebrate's $J$ Palaeogeogr 3 90-98

Saraswati P K, Banerjee S, Sarkar U, Chakraborty S and Khanolkar S (2016a) Eocene Depositional Sequence and Cycles in Kutch Spl Publ Geol Soc India 6 46-56

Saraswati P K, Khanolkar S, Raju D S N and Banerjee S (2016b) An updated Eocene stratigraphy of Kutch Spl Publ Geo Soc India 6 25-31

Saraswati P K, Khanolkar S and Banerjee S (2018) Paleogene stratigraphy of Kutch, India: an update about progress in foraminiferal biostratigraphy Geodinamica Acta 30 100118

Sarkar S (1988) Petrology of caliche-derived peloidalcalcirudite/ calcarenite in the late Triassic Maleri Formation of the Pranhita-Godavari valley, south India Sediment Geol $\mathbf{5 5}$ 263-282

Sarkar S, Chakraborty N, Mandal A, Banerjee S and Bose P K (2014) Siliciclastic-carbonate mixing modes in the rivermouth bar palaeogeography of the Upper Cretaceous Garudamangalam Sandstone (Ariyalur, India) $J$ Palaeogeogr 3 233-256

Sarkar U, Banerjee S and Saraswati P K (2012) Integrated borehole and outcrop study for documentation of sea level cycles within the Early Eocene Naredi Formation, western Kutch, India $J$ Palaeogeogr 1 126-137

Sengupta S, Sengupta D P and Bandyopadhyay S (2016) Stratigraphy of the upper Gondwana formations around Sohagpur, western part of the SatpuraGondwana Basin, Central India J Geol Soc India 87 503-519

Sharma J and Saraswati P K (2015) Lignites of Kutch, Western India: Dinoflagellate biostratigraphy and palaeoclimate $\mathrm{Rev}$ de Micropaleontol 58 107-119

Shekhar S, Shukla A and Kumar P (2018) Sedimentary record of forced regression along the margin of Kutch Basin: Terminal Cenozoic succession (Sandhan Formation), western India J Indian Ass of Sedimentol 35 23-35
Sonkusare H, Samant1 B and Mohabey D M (2016) Microflora from Sauropod Coprolites and Associated Sediments of Late Cretaceous (Maastrichtian) Lameta Formation of Nand-Dongargaon Basin, Maharashtra J Geol Soc India 89 391-397

Sridhar A, Bhushan R, Balaji D, Band S and Chamyal L S (2016) Geochemical and $\mathrm{Sr}-\mathrm{Nd}$ isotopic variations in palaeoflood deposits at mainstem-tributary junction, western India: Implications on late Holocene flood events Catena 139 $32-43$

Sridhar A and Chamyal L S (2018) Implications of palaeohydrological proxies on the late Holocene Indian Summer Monsoon variability, western India Quat Int 479 $25-33$

Srivastava A K and Bansod M N (2019) Morphology and field association of calcretes from Quaternary sediments of Purna alluvial basin, Maharashtra Proc Natl Acad Sci India, Sect A Phys Sci doi: 10.1007/s40010-019-00164-7

Srivastava A K and Mankar R S (2015) Megaloolithus dinosaur nest from the Lameta Formation of Salbardi area, districts Amravati, Maharashtra and Betul, Madhya Pradesh J Geol Soc India $\mathbf{8 5}$ 457-462

Srivastava A K and Singh A (2019a) YTT ash from Quatemary sediments of Kapileshwar area, Purna alluvial basin, central India Ouat Int 500 96-107

Srivastava A K and Singh A (2019b) Nature, occurrence and lithological set up of Youngest Toba Tuff. volcanic ash. Purna alluvial basin, central India J Geol 127 1-18

Srivastava A K, Bansod M N, Singh A and Sharma N (2019) Geochemistry of Paleosols and calcretes from Quaternary sediments of Purna alluvial basin, central India : An emphasis on paleoclimate Rhizosphere 11 1-12

Srivastava A K, Kandwal N K, Humane S K, Humane S S, Kundal $P$ and Khare N (2018) Record of calcareous algae from the Lameta Formation: a new insight for possible sea incursion during the Maastrichtian time Arabian J Geos 11.14. https:/ /doi.org/10.1007/s12517-017-3333-1

Srivastava V K and Singh B P (2019) Depositional environments and sources for the middle Eocene Fulra Limestone Formation, Kachchh Basin, western India: Evidences from facies analysis, mineralogy, and geochemistry Geo $J \mathbf{5 4}$ $62-82$. 